\title{
Apoptosis in Pulp Elimination During Physiological Root Resorption in Human Primary Teeth
}

\author{
Luciana Villela RODRIGUES \\ Anilton César VASCONCELOS \\ Pedro Alves CAMPOS \\ Juliana Massote Caldeira BRANT \\ Laboratory of Apoptosis, Department of General Pathology, Institute of Biological Sciences, \\ Federal University of Minas Gerais, Belo Horizonte, MG, Brazil
}

\begin{abstract}
Pulp samples of 50 healthy human teeth with indication for extraction were examined to evaluate the role of apoptosis in pulp elimination during physiological root resorption. Two groups were formed: a test group $(n=30)$ composed of pulp samples of primary teeth with physiological root resorption and a control group $(n=20)$ composed of pulp samples of permanent maxillary third molars. Morphological evidence of apoptosis as well as in situ detection of cellular DNA fragmentation by TUNEL assay and detection of internucleosomal pattern of fragmentation of the genomic DNA by electrophoresis were observed. The apoptotic index of the primary tooth group was significantly higher than that of the permanent tooth group $(51.01 \pm 0.52$ versus $25.32 \pm 0.68)(p<0.001)$. TUNEL reaction showed intense and diffuse labeling in the pulp samples of primary teeth, which were discrete in the controls. Intense DNA internucleosomal fragmentation, a specific pattern for apoptosis, was observed in primary tooth pulps DNA by electrophoresis, in the permanent tooth pulps this pattern fragmentation of the genomic DNA for apoptosis were not present. These results seem to indicate a role of apoptosis in pulp elimination during the physiological root resorption of human primary teeth.
\end{abstract}

Key Words: apoptosis, physiological root resorption, human primary teeth.

\section{INTRODUCTION}

Root resorption is a physiological process in the life span of human primary teeth, which lose support in the oral cavity to give place to the permanent dentition $(1,2)$.

The dental pulp is a specialized connective tissue with a peculiar organization and location. It is surrounded by dentin, which is a hard and inelastic tissue, and presents fibroblasts, odontoblasts, endothelial cells, collagen fibers, glycosaminoglycans, lymphocytes, macrophages, bloods vessels and nerves (3). During the physiological root resorption in primary teeth, the pulp is also eliminated. However, the sequence of events and the mechanism responsible for the physiological death of pulp cells remain unclear (4-7).

Apoptosis is a type of physiological and programmed cell death characterized by structural and functional modifications in the cell (8). The action of endonucleasis is responsible for the morphologic alterations observed in apoptotic cells. Endonucleasis breaks up the DNA of the cell generating fragments with 200 base-pairs or its multiples. The cell is stimulated to activate mechanisms that will result in its death, without inducing inflammatory reactions (9). Therefore, it is suggested that apoptosis may play a role in pulp elimination due to the programmed nature and absence of inflammatory reaction in the physiological root resorption of human primary teeth (4).

The aim of this study was to evaluate the role of apoptosis in the elimination of pulp cells during the physiological root resorption of human primary teeth. For such purpose, morphological evidence of apoptosis as well as in situ detection of cellular DNA fragmentation by TUNEL (terminal deoxynucleotidyl transferasemediated-UTP nick end-labeling) assay and detection of internucleosomal pattern of fragmentation of the genomic DNA by electrophoresis were used. 


\section{MATERIAL AND METHODS}

\section{Primary Tooth Pulps (Test Group)}

Pulps of 30 healthy human primary teeth with indication for extraction were collected and processed for either histological examination or DNA extraction. Prior to extraction, clinical and radiographic examinations confirmed that the teeth were free of cracks, fractures or any pathology that could have contaminated their pulps, and had at least $1 / 3$ of physiological root resorption (Fig. 1A). Immediately after tooth extraction in a surgical environment, the dental pulps were collected with a sterile Rollemback through the apical foramen. Twenty pulps were collected and fixed in $10 \%$ formalin for $4 \mathrm{~h}$ before being subjected to routine histological processing for morphometric analysis and TUNEL reaction. The remaining 10 pulps were stored in TTE buffer (Tris $10 \mathrm{mM}$, Triton X-100 0.25\%, EDTA $1 \mathrm{mM}$ ) and immediately frozen in liquid nitrogen for DNA extraction and agarose gel electrophoresis. All pulp samples were collected in the Pediatric Dentistry Clinic of the Dental School of the Pontifical Catholic University of Minas Gerais, Brazil. All procedures were approved by the local Research Ethics Committee (CAAE 0037021300006) and the parents/guardians signed an informed consent form authorizing donation of the teeth for the study.

\section{Permanent Tooth Pulps (Control Group)}

Pulps of 20 healthy immature human maxillary third molars with indication for extraction were collected and processed for either histological examination or DNA extraction. Prior to extraction, clinical and radiographic examinations confirmed that the teeth were free of cracks, fractures or any pathology that could have contaminated their pulps (Fig. 1B). Immediately after tooth extraction in a surgical environment, the dental pulps were collected in the same way as described for the primary teeth. Fifteen pulps were collected and fixed in $10 \%$ formalin for $4 \mathrm{~h}$ before being subjected to routine histological processing for morphometric analysis and TUNEL reaction. The remaining 5 pulps, used for DNA extraction and agarose gel electrophoresis, were stored in TTE and immediately frozen in liquid nitrogen. All the samples were collected in the surgery clinic of the PUC-MG. All pulp samples were collected in the Dental Surgery Clinic of the Dental School of the Pontifical Catholic University of Minas Gerais, Brazil. All procedures were approved by the local Research Ethics Committee (CAAE 0037021300006) and all patients signed an informed consent form authorizing donation
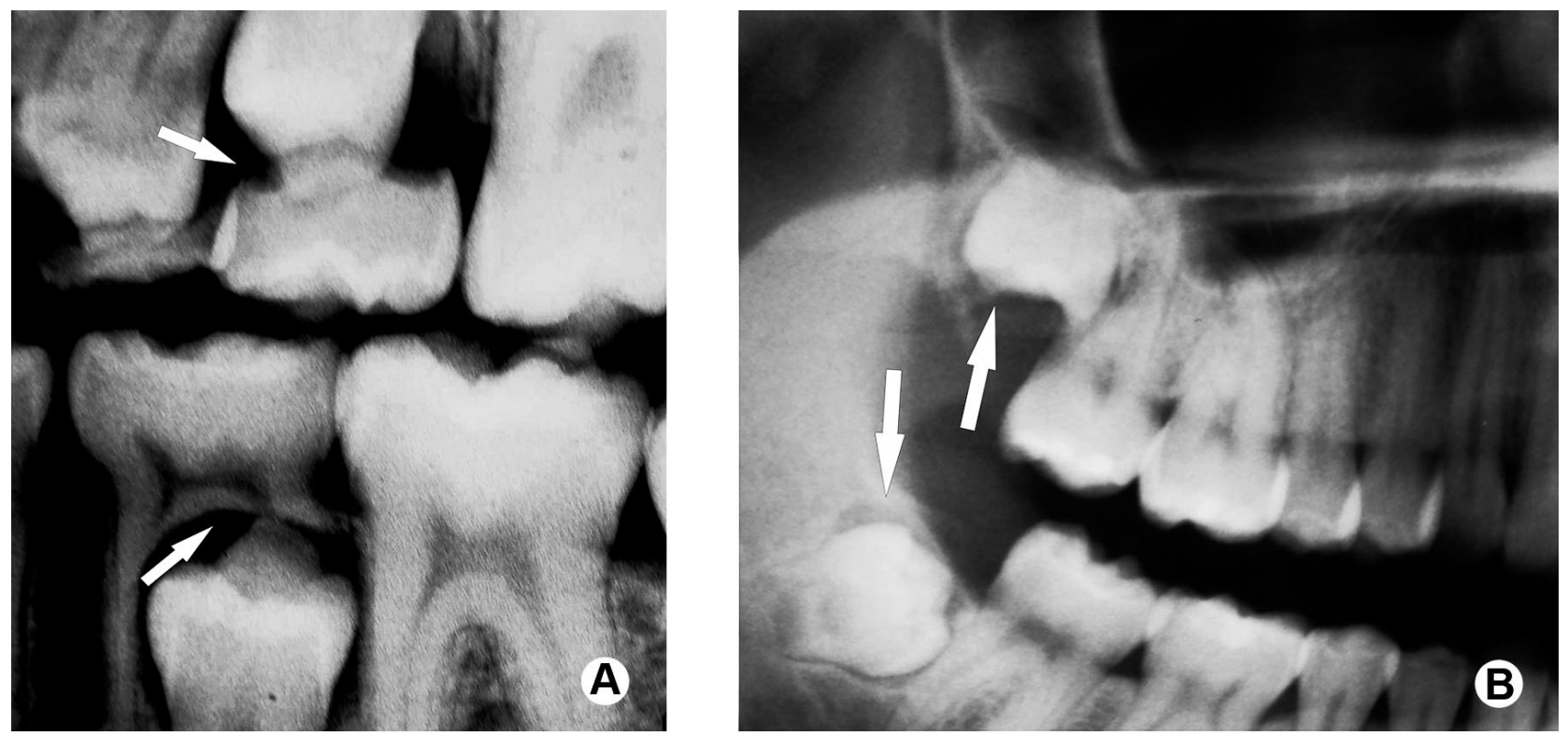

Figure 1. Preoperative radiographs showing that all teeth were free of cracks, fractures or any pathology. Primary had at least $1 / 3$ of physiological root resorption (A) and permanent teeth (control group) had incomplete root formation (B). 
of the teeth for the study.

\section{Histological Processing}

The pulp samples were embedded in paraffin and the sections obtained were stained with hematoxylin and eosin (HE) and Gomori's Trichrome (GT) (10) for morphometrical analysis and TUNEL reaction in order to confirm apoptosis by in situ detection of DNA fragmentation (11). A commercial kit was used (Klenow-FragEL ${ }^{\text {TM }}$ DNA Fragmentation Detection Kit; QIA21 catalogue; Calbiochem/Oncogene, Darmstadt, Germany). Reactions were carried out as indicated by the manufacturer. Briefly, slides were incubated at $50^{\circ} \mathrm{C}$ for $1 \mathrm{~h}$ and immersed in two 5-min changes of xylenes for deparaffinization. Then, the slides were hydrated in a decreasing ethanol series (100, 95 and 70\%, 5 min each), washed twice in 1 x PBS (5 min each), permeabilized with $20 \mu \mathrm{g} / \mathrm{mL}$ proteinase $\mathrm{K}$ for $20 \mathrm{~min}$, and endogenous peroxidase was quenched 3 times with $3 \% \mathrm{H}_{2} \mathrm{O}_{2}$ in methanol. TdT (terminal deoxynucleotidyl transferase) and deoxynucleotides were applied and slides were placed in humid atmosphere at $37^{\circ} \mathrm{C}$ for approximately $6 \mathrm{~h}$. The reaction was stopped by a blocking buffer, and then slides were treated with peroxidase streptavidin conjugate, placed in humid atmosphere at $37^{\circ} \mathrm{C}$ for $1 \mathrm{~h}$. Finally, the slides were washed with $1 \mathrm{x}$ PBS, treated with diaminobenzidine and counterstained with methyl-green.

\section{Morphometric Analysis}

A cutoff value of the minimal representative number of microscopical fields was established to perform the morphometry, as described elsewhere (12). The number of microscopic fields was considered representative when an increase in the number of fields measured did not result in considerable decrease in the coefficient of variation. By using this approach, 25 microscopic fields per slide were established as suitable to quantify the number of apoptotic cells and the apoptotic index. Images of 25 fields from each slide were digitized using a $\times 100$ planachromatic objective. Quantification of the apoptotic and normal cells were performed in a blind fashion by a single observer using an image-processing software (Kontron KS300 v. 2.0; Kontron Elektronik Gmbh, Germany). Cells were considered apoptotic only when showing at least 3 of the following morphological criteria: 1) Anoikia (cellular retraction and loss of adhesion between cells and matrix); 2) Cytoplasm condensation; 3) Nuclear condensation (nuclear chromatin dense, sometimes lined up in the nuclear membrane, with a "crescent" pattern); 4) Nuclear fragmentation; and 5) Formation of apoptotic bodies.

The Apoptotic Index (AI) was obtained using the following equation: $\mathrm{AI}=[\Sigma$ number of apoptotic cells / ¿number of total cells] x 100 .

\section{Statistical Analysis}

Results were expressed as mean \pm standard error, after confirmation of the normal distribution of data by the Kolmogorov-Smirnov test. Data from primary and permanent teeth were subjected to ANOVA and Tukey's test. Values of $p<0.001$ were considered significant and GraphPad Prism, v.3.0 (GraphPad Software, Inc., San Diego, CA, USA) was used for statistical analyses.

\section{Electrophoresis in Agarose Gel}

Pulp cells were lysed with $0.5 \mathrm{~mL}$ of hypotonic lysis buffer TTE (10 mM Tris, $0.25 \%$ Triton $x-100,1 \mathrm{mM}$ EDTA). Proteins were removed by phenol-chloroformisoamylalcohol $(25: 24: 1)$ extraction. The DNA was precipitated with $1 / 10$ volume of $3 \mathrm{M}$ sodium acetate and 2 volumes of cold absolute ethanol at $-20^{\circ} \mathrm{C}$ overnight. DNA pellets were washed in $75 \%$ ethanol twice, dried and suspended in $10 \mathrm{mM}$ Tris- $\mathrm{HCl}$ (pH 7.4) $1 \mathrm{mM}$ EDTA. The amounts of DNA in each of the samples were measured with a spectrophotometer (GeneQuant; GE Healthcare, Amersham, Buckinghamshire, UK). Aliquots of $15 \mu \mathrm{L}$ containing approximately $4.000 \mathrm{ng}$ of DNA were then electrophoresed in 1.8\% agarose for $1 \mathrm{~h} 30 \mathrm{~min}$ at $60 \mathrm{~V}$. Gels were stained with ethidium bromide and photographed under UV transillumination.

\section{RESULTS}

Apoptosis was evident in pulps of primary teeth during the root resorption process. HE- and GT-stained histological sections (Figs. 2A and 2B, respectively) showed shrunken cells, with clear halos surrounding them (anoikia) and cytoplasm and nuclear condensations. Frequent presence of apoptotic bodies and absence of inflammation also contributed for characterizing the occurrence of apoptosis at the histological level. In the permanent tooth pulps, the presence of apoptotic cells 

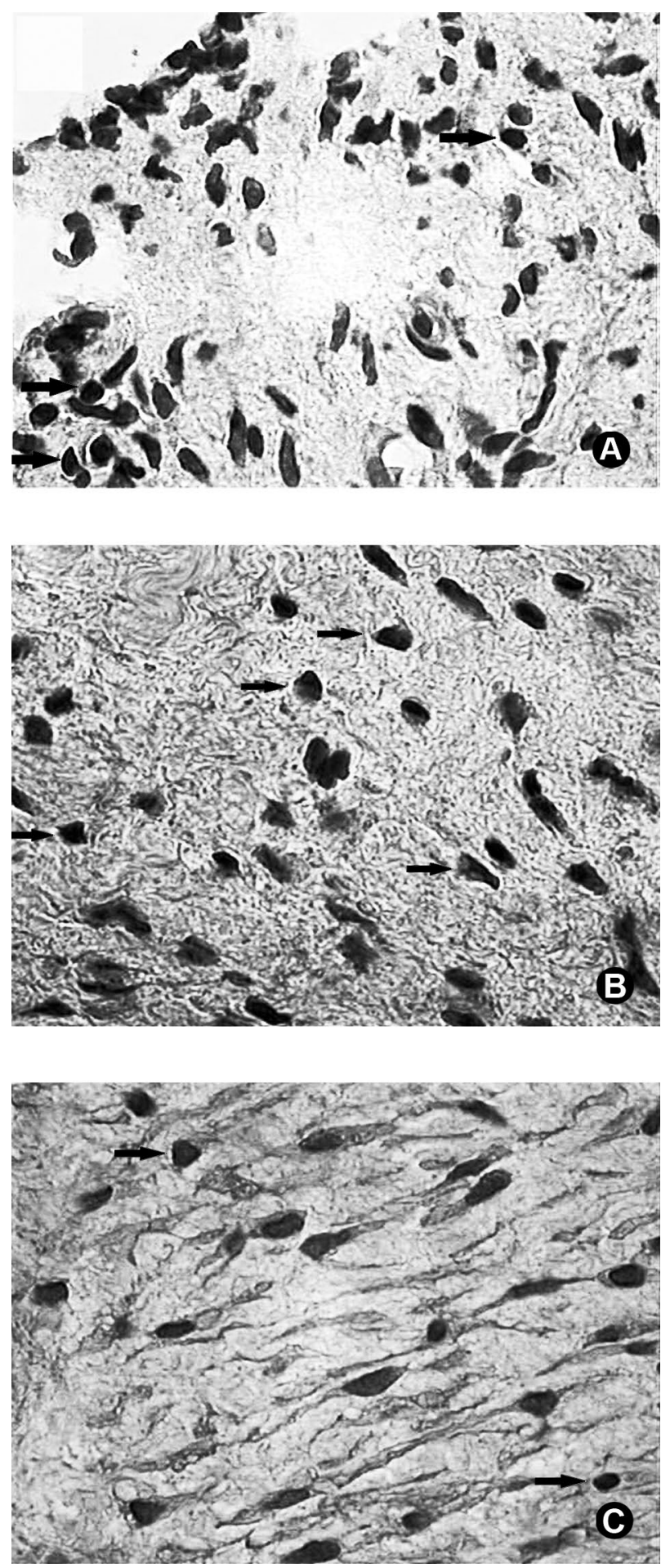

Figure 2. Photomicrograph of pulp samples of a primary tooth stained with hematoxylin and eosin (A) and Gomori's Trichrome (B) and human permanent tooth (control group) stained with hematoxylin and eosin HE $(C)$ (original magnification $\times 1000$ ). Note in A and B the presence of shrunken apoptotic cells with clear halos surrounding them (anoikia) and condensed nuclei. These findings are scarce in the permanent teeth (C). was clearly less intense (Fig. 2C).

The in situ detection of DNA fragmentation by TUNEL reaction showed ample labeling in primary teeth pulp samples with physiological root resorption (Fig. $3 \mathrm{~A})$. The nuclei of the apoptotic cells had dark brownish dots, resulted from peroxidase reaction with its substrate, diaminobenzidine. In the permanent tooth pulps, positive labeling of the TUNEL reaction for fragmentation of the genomic DNA was discrete (Fig. 3B).

The apoptotic index of the primary tooth group was significantly higher than that of the permanent tooth group $(51.01 \pm 0.52$ versus $25.32 \pm 0.68)(\mathrm{p}<0.001)$.

Intense DNA internucleosomal fragmentation, a specific pattern for apoptosis, was observed in primary tooth pulps (Fig. 4). DNA fragments were identified as bands by gel electrophoresis, and longer fragments were also detected as a smear in the gel near the origin of migration. On the other hand, the lane of the permanent teeth (controls) showed a more intense smear near the origin of migration. There were some weaker bands ("background apoptosis"), indicating that most part of the DNA in these teeth was still unfragmented as compared to the primary tooth pulp samples.

\section{DISCUSSION}

Physiological root resorption is a phenomenon that occurs only in the primary dentition. In the permanent dentition, root resorption is associated with external events, such as inadequate occlusal forces, periodontal pathology, microtraumatisms, ectopic eruption of neighboring teeth, among others (13).

During physiological resorption, all root tissues (cementum, dentin and pulp) are eliminated (4). Cementum and dentin are eliminated by the action of odontoclasts or osteoclasts, which are specialized in the resorption of these dental tissues (14-17). Although the way odontoclasts are recruited and activated is still controversial, the resorption of cementum and dentin in primary teeth seems to be regulated in a similar manner to bone remodeling $(4,5,17)$. According to Sasaki $(16)$, the permanent tooth follicle and its periodontal ligaments adjacent to primary tooth, recruit, develop and activate odontoclasts, playing an important role in root resorption of primary teeth. Domon et al. (5) detected odontoclast fragments of various sizes suggesting apoptosis during the physiological root resorption in human primary teeth. Most studies have focused only on the 
elimination of the root's hard structures. However, the literature is also vague on how resorption of the pulp of the primary teeth occurs. The mechanism responsible for the physiological death and resorption of pulp cells has not yet been studied yet (4-7).

The turnover of pulp cells as well as the occurrence and the meaning of physiological pulp cell death need to be clarified. The presence of apoptotic cells in the odontoblastic and subodontoblastic layers in rats and human has been described (4).

This study investigated the elimination of pulp cells during physiological root resorption in human primary teeth. The morphometric analysis using the AI showed that apoptosis in pulps of primary teeth was more intense than in pulps of permanent teeth. TUNEL reaction demonstrated an increased in situ detection of DNA fragmentation in primary tooth pulps. TUNEL labeling was more intense and diffused in pulps of primary teeth than in pulps of permanent teeth. This study also provides evidence that the cellular DNA fragmentation occurred in an internucleosomal way, which is a typical occurrence of apoptosis, as demonstrated by the ladder pattern in genomic DNA electrophoresis. These findings seem to support that apoptosis is involved in pulp cell elimination in physiological root resorption in human primary teeth.

The primary teeth used in this study were in an advanced stage of root resorption, with $1 / 3$ or more of the root surface already resorbed eliminated. When the level of root resorption does not exceed $1 / 3$ of the root

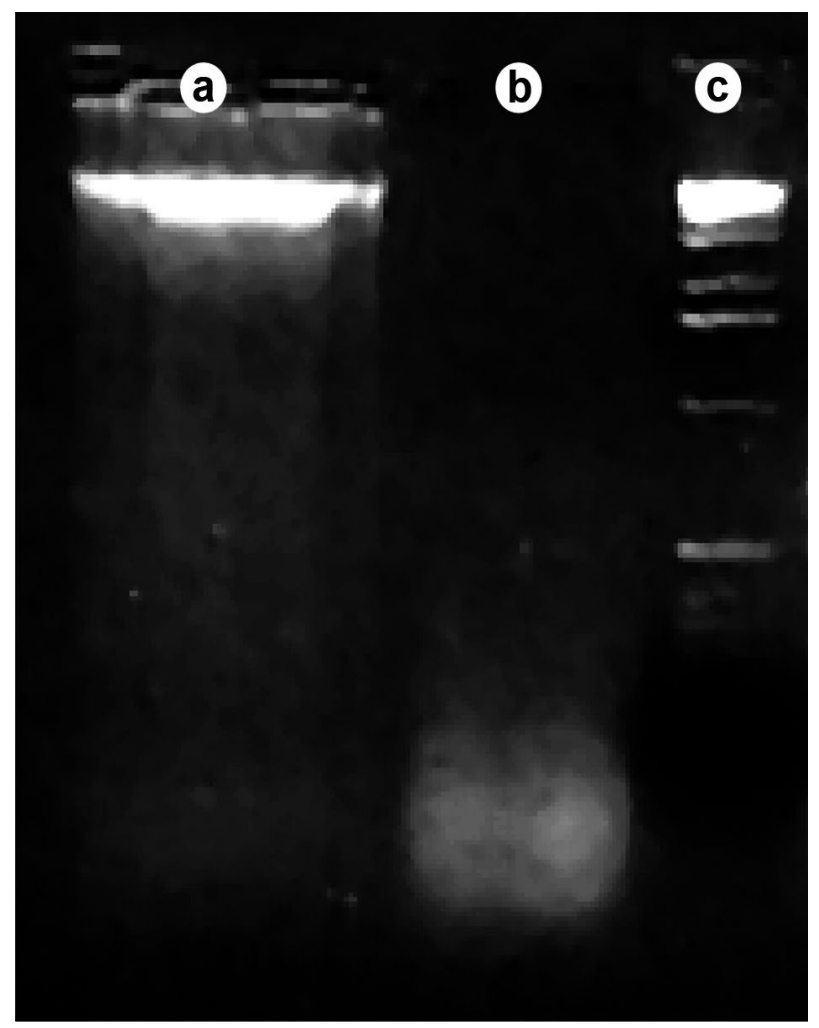

Figure 4. Agarose gel electrophoresis of the genomic DNA. First lane (A): Permanent teeth showing a more intense smear near the origin of migration. There were some weaker bands ("background apoptosis"), indicating that most part of the DNA was still unfragmented. Second lane (B): Primary tooth pulps showing an internucleosomal DNA fragmentation, a specific pattern for apoptosis. Third lane (C): DNA markers of 200 base-pairs.
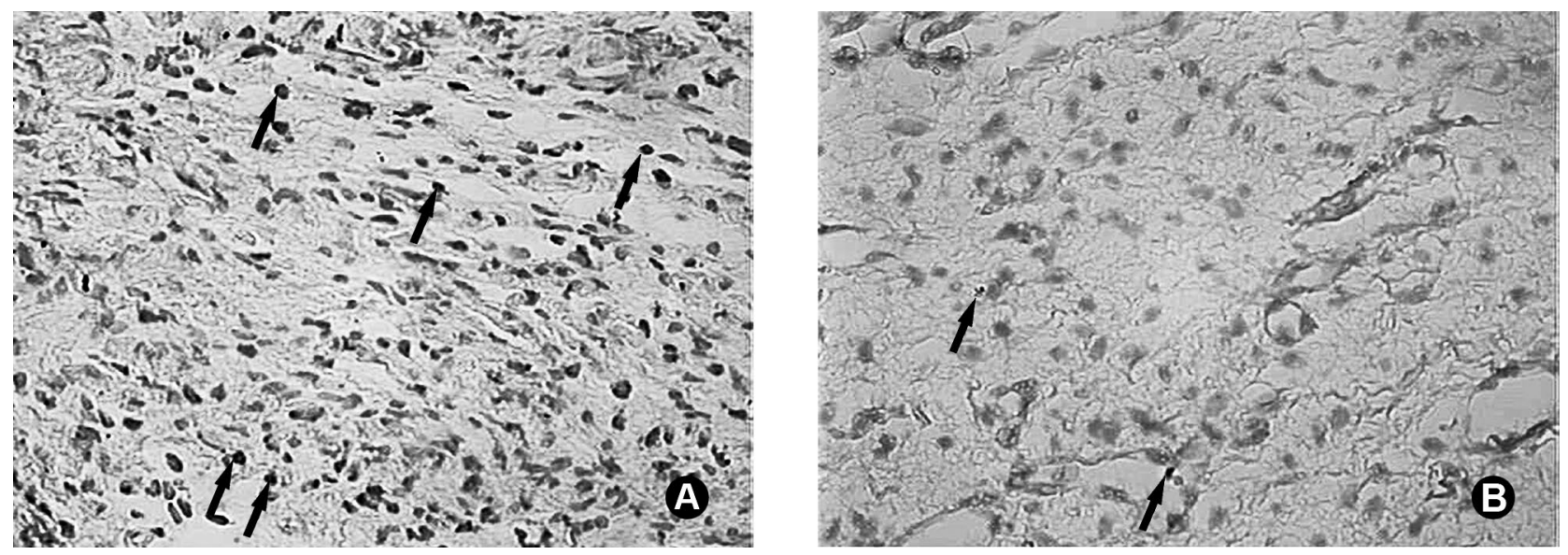

Figure 3. Photomicrographs of pulp samples of human primary (A) and permanent (B) teeth (TUNEL reaction; original magnification $\times 400$ ). Intense diffuse labeling for genomic fragmentation in A and scarce or insignificant labeling in B. 
surface the stage is defined as precocious (18).

Without considering apoptosis, Simsek and Duruturk (19) concluded that no structural differences exist between pulps of primary teeth with physiological root resorption and of young permanent teeth. Similarly, previous study (13) comparing primary teeth with physiological root resorption and young permanent teeth, verified that histologically these dental groups are identical. It has been shown that primary teeth retain the potential for sensation, healing, and repair until reaching advanced stages of physiological root resorption (6). Such findings support the use of the pulp of third molar permanent teeth, with incomplete root formation, as a control group in this study.

The interactive role of the pulp tissue in the physiologic root resorption process has been described, although not considering apoptosis. According to Eronat et al. (2), an increased pulp metabolism takes place in the physiological root resorption in primary teeth detectable through the AgNOR staining technique. Yildirim et al. (7) suggest that dental pulp may have cytokine-producing cells which would mediate monocyte-macrophage lineage to form osteo/odontoclasts involved in human primary tooth resorption. Such findings seem to indicate a role of the pulp in the physiological root resorption and support studies focusing cellular population in dental pulp.

Two essential processes are involved during the permanent teeth eruption: root resorption of the primary teeth and the proper mechanism of permanent teeth eruption. Although these 2 processes occur simultaneously, it was demonstrated that they are not conducted by a single physiological mechanism. Evidence exists of the occurrence of physiological root resorption of primary teeth in the absence of corresponding permanent teeth $(1,2)$.

According to Marks and Schroeder (1), permanent tooth eruption is guided by the periodontal ligaments. However, the way this eruptive force is activated and the mechanism of the radicular resorption of primary teeth still remain unclear. Besides the mechanic-compressive forces involved in the permanent tooth eruption, it is possible that apoptosis in dental pulp of primary teeth may also participates in the elimination of the other root structures.

Apoptosis is essential to balance mitosis (16). As a programmed and active cell death, apoptosis requires energy, synthesis and protein degradation (9), and serves for live organisms to eliminate potentially harmful cells and maintain homeostasis (8). Apoptosis is thus a physiological mechanism of cellularity control, regulating the size of tissues in an inverse situation of mitosis (20). The dental pulp, as most livings tissues, is constantly renewed. This means a coupling between cellular proliferation (by mitosis) and resorption (by apoptosis). Therefore the occurrence of some apoptosis is not unexpected in permanent tooth pulps. The lower AI, the weaker labeling with the TUNEL reaction and the weaker internucleosomal DNA fragmentation in genomic electrophoresis in this study are a consequence of a regular turnover of permanent dental pulps.

Several studies have focused on the occurrence of necrosis in dental tissues, but very few have dealt with apoptosis and its role in physiological root resorption of primary teeth $(4-7,20)$.

Despite all controversies and scarcity of similar studies in the literature, the results of the present study seem to indicate the participation of apoptosis in pulp tissue elimination during physiological resorption of human primary teeth. Findings that support this conclusion include the programmed nature of apoptosis, the absence of inflammation, the morphological features of apoptotic cells, the morphometric results, the in situ detection of DNA fragmentation by TUNEL reaction, and the internucleosomal pattern of genomic cleavage verified by electrophoresis.

\section{RESUMO}

Cinqüenta amostras de polpas de dentes humanos hígidos com indicação para extração foram estudadas a fim de verificar a participação da apoptose na eliminação pulpar durante a reabsorção radicular fisiológica. As amostras foram divididas em 2 grupos: um grupo de estudo composto por 30 polpas de dentes decíduos hígidos com reabsorção radicular físiológica, e um grupo controle composto por 20 polpas de terceiros molares superiores hígidos. Evidências morfológicas de apoptose, bem como detecção in situ da fragmentação do DNA genômico via reação de TUNEL e também a detecção do padrão internucleossômico de fragmentação do DNA genômico via eletroforese foram observados. $\mathrm{O}$ índice apoptótico foi maior no grupo de dentes decíduos $(51,01 \pm 0,52)$ quando comparado ao grupo de dentes permanentes $(25,32 \pm 0,68)(\mathrm{p}<0,001)$. Quanto à reação de TUNEL, houve intensa marcação positiva para fragmentação do genoma no grupo de estudo, o que ocorreu de maneira discreta nos controle. A eletroforese do DNA genômico mostrou fragmentação internucleossômica, em um padrão específico de apoptose nas amostras de dentes decíduos o que não ocorreu no grupo de dentes permanentes. Estes achados parecem indicar a apoptose como um mecanismo importante na eliminação do tecido pulpar durante a reabsorção radicular fisiológica de dentes decíduos humanos. 


\section{REFERENCES}

1. Marks SC, Schroeder HE. Tooth eruption: teories and facts. Anat Rec 2001;245:374-393.

2. Eronat C, Eronat N, Aktug M. Histological investigation of physiologically resorbing primary teeth using Ag-NOR staining method. Int J Paed Dent 2002;12:207-214.

3. Abrahão IJ, Martins MD, Katayama E, Antoniazzi JH, Segmentilli A, Marques MM. Collagen analysis in human tooth germ papillae. Braz Dent J 2006;17:208-212.

4. Harokopakis-Hajishengallis E. Physiologic root resorption in primary teeth: molecular and histological events. J Oral Sci 2007;49:1-12.

5. Domon $\mathrm{T}$, Taniguchi $\mathrm{Y}$, Inove K, Ushijima N, Taishi Y, Hiramatsu A, et al.. Apoptosis of odontoclasts under physiological root resorption of human deciduous teeth. Cell Tissue Res 2008;331:423433.

6. Monteiro J, Day P, Duggal M, Morgan C. Pulpal status of human primary teeth with physiological root resorption. Int J Paediatr Dent 2009;19:16-25.

7. Yildirim S, Yapar M, Sermet U, Sener K, Kubar A. The role of dental pulp cells in resorption of deciduous teeth. Oral Surg Oral Med Oral Pathol Oral Radiol Endod 2008;105:113-120.

8. Arends MJ, Wyllie AH. Apoptosis: mechanisms and roles in pathology. Internat Rev Exp Pathol 1991;32:223-254.

9. Cohen JJ. Apoptosis. Immunol Today 1993;14:126-130.

10. Luna LG. Manual of Histology. Staining methods of Armed Forces Institute of Pathology. 3th ed. New York:McGraw-Hill,1968.

11. Gavrieli Y, Sherman Y, Ben BS. A identification of programmed cell death in situ via specific labeling of nuclear DNA fragmentation. J Cell Biol 1972;119:493-501.
12. Moro L, Vasconcelos AC, Santos FGA, Alves CM, Nunes IBM Determination of the minimal representative number of microscopic fields to quantify apoptosis in canine lymph nodes. Arq Bras Med Vet Zootec 2004;56:408-410.

13. Sari $\mathrm{S}$, Aras $\mathrm{S}$, Gunhan $\mathrm{O}$. The effect of physiological root resorption on the histological structure of primary tooth pulp. J Ped Dent1999;23:221-225.

14. Takada K, Kajiya H. Calcitonin in human odontoclasts regulates root resorption activity via protein kinase A. J Bone Miner Metab 2004;22:12-18.

15. Kimura R, Anan H. Dental root resorption and repair: histology and histometry during physiological drift of rat molars. J Period Res 2003;38:525-532.

16. Sasaki T. Differentiation and functions of osteoclasts and odontoclasts in mineralized tissue resorption. Mic Res Tech 2003;61:483495.

17. Domon T, Osanai M. Ultrastructural study of the root dentine surface resuming resorption on human deciduous teeth. Ann Anat 2000;182:175-184

18. Scarola V, Galmozzi A. Biologia dei processi di riassorbimento radicolare dei denti decidui. Min Stomatol 2001;50:145-150

19. Simsek S, Duruturk L. A flow cytometric analysis of the biodefensive response of deciduous tooth pulp to carious stimuli during physiological root resorption. Arc Oral Biol 2005;50:461-468.

20. Nishikawa S, Sasaki F. Apoptosis of dental pulp cells and their elimination by macrophages and MHC class II expressing dendritic cells. J Hist Cyto 1999;47:303-311.

Accepted August 11, 2009 